\title{
Correction to: The U.S. Homeless Student Population: Homeless Youth Education, Review of Research Classifications and Typologies, and the U.S. Federal Legislative Response
}

\author{
Mai Abdul Rahman' ${ }^{1}$ J. Fidel Turner ${ }^{2} \cdot$ Salman Elbedour $^{2}$
}

\section{Correction to: Child Youth Care Forum (2015) 44:687-709 DOI 10.1007/s10566-014-9298-2}

The author regrets that typographical error occurred in values on page 702 , second paragraph, lines 3 and 4 . The correct values are $\$ 69.61$ and $\$ 55.78$. These values are corrected by this erratum. The lines should now read as, "EHCY's federal appropriations in 2009 totaled $\$ 65,427,000$ for 939,903 homeless students (\$69.61 per student) (CRS 2012). In 2012, EHCY served 1,168,354 homeless students, yet federal funds appropriated to EHCY totaled $\$ 65,173,000$ (\$55.78 per student) (NAEHCY 2012).”

The online version of the original article can be found under doi:10.1007/s10566-014-9298-2.

Mai Abdul Rahman

maifordcschools@gmail.com

J. Fidel Turner

johnnie.f.turner@howard.edu

Salman Elbedour

selbedour@howard.edu

1 School of Education, Educational Leadership and Policy, Howard University, 3318 Stephenson Place, NW, Washington, DC 20015, USA

2 Department of Psychology, School of Education, Howard University, 2441 4th Street, NW, Washington, DC 20059, USA 